\title{
Energy and nutritional inadequacies in a group of recreational adult Spanish climbers
}

\author{
Natalia Úbeda, Carlota Lorenzo-Carvacho, Ángela García-González \\ Department of Pharmaceutical Sciences and Health. Universidad San Pablo-CEU. CEU Universities. Madrid. Spain.
}

doi: 10.18176/archmeddeporte.00047

Recibido: $20 / 06 / 2020$

Aceptado: 18/03/2021

Key words:

Rock climbing. Nutritional assessment. Body composition. Dietary inadequacies.

\section{Summary}

Introduction: Although nutrition is determinant in the performance of athletes, few publications on this topic are available for climbers.

Objectives: To measure body composition and dietary intake in a group of recreational Spanish climbers.

Material and method: For body composition data we performed the measurements included in the ISAK anthropometric restricted- profile. Daily dietary intake was self-recorded on 3 days of the week: a non-climbing day, a climbing-gym training day and a rock- climbing day. Results were compared to Spanish nutritional recommendations.

Results: 61 climbers (44 men, 17 women), aged $34 \pm 8$ years, volunteered. Body fat \% was $8.1 \pm 1.5 \%$ in men and $15.7 \pm 3.0 \%$ in women. A negative correlation was found between body fat \% and climbing ability $(P<0.0005)$. Intake of energy and carbohydrates was $40 \%$ below estimated targets and that of proteins was 20-25\% below. Moreover, macronutrient contribution to energy was unbalanced (protein: fat: $\mathrm{CHO}$ : alcohol was 17: 38: 42: 3\%). We observed an elevated intake of SFA and sugars and low consumption of MUFA and fiber. Micronutrient intakes were acceptable except for iodine, zinc and vitamin D in both genders and iron and folate in women. Mean Adequacy Ratio of diet was higher in advanced/elite climbers compared with those in the intermediate level showing a possible relationship between climbing ability and diet quality.

Conclusions: This study evidences there is a need of nutritional recommendations targeted to climbers. Our findings can contribute to the design of evidence-based food guides to help climbers optimise health and performance outcomes.
Palabras clave:

Escalada. Evaluación nutricional. Composición corporal. Deficiencias dietéticas.

\section{Deficiencias energéticas y nutricionales en un grupo de escaladores recreacionales españoles adultos}

\section{Resumen}

Introducción: Existen pocos estudios sobre la relación entre dieta y rendimiento en escaladores. Objetivos: Averiguar la composición corporal y la dieta en un grupo de escaladores recreativos.

Material y método: Se midió el perfil antropométrico restringido ISAK. La ingesta fue autoregistrada en un día sin escalada, un día de entrenamiento en el rocódromo y un día de escalada en roca. Los resultados se compararon con las recomendaciones nutricionales españolas.

Resultados: Participaron 44 hombres y 17 mujeres, de $34 \pm 8$ años. El \% de grasa corporal fue 8,1 1,5\% en hombres y $15.7 \pm 3.0 \%$ en mujeres. Se encontró una correlación negativa entre grasa corporal y el grado de escalada $(P<0,0005)$. La ingesta de energía y carbohidratos fue un $40 \%$ inferior a la estimada para cubrir los requerimientos y la de proteínas un 20-25\% inferior. El perfil calórico de la dieta estaba desequilibrado (proteína: grasa: $\mathrm{CHO}$ : alcohol = 17:38:42:3\%). El consumo de AGS y azúcares fue elevado y bajo el de AGM y fibra. Se observaron carencias en yodo, zinc y vitamina D en ambos sexos y en hierro y folatos en las mujeres. La calidad de la dieta fue mayor en los escaladores avanzados/élite comparada con la de los de nivel intermedio, lo que indica una posible relación entre esta y el grado alcanzado en escalada.

Conclusiones: Se evidencia la necesidad de recomendaciones nutricionales dirigidas a los escaladores. Nuestros hallazgos pueden contribuir al diseño de guías alimentarias basadas en la evidencia, que optimicen la salud y el rendimiento de estos deportistas. 


\section{Introduction}

Sport climbing is becoming increasingly popular. Climbing can be performed for recreational purposes or as competition, on both natural rocks and indoors ${ }^{1}$. In Tokyo 2021, sport climbing will debut in the Olympic Games in three categories: leading, bouldering and speed climbing.

Several studies have focused on the anthropometric and physiological characteristics of climbers. These have observed a high heart rate and $\mathrm{VO}_{2 \text { peak }}$ together with an increased lactate concentration, possibly resulting from repeated isometric contractions, indicating a contribution of both aerobic and anaerobic energy systems during climbing ${ }^{2,3}$. Previous studies also found anthropometric features in elite climbers characterized by a small stature, with high muscular endurance, high flexibility, low body mass and body fat content and high handgrip strength related to body mass ${ }^{4-7}$. These characteristics could play a major role in determining sport success ${ }^{8}$.

However, other studies, like that of Mermier et al (2000)5, found that training variables explained $58.9 \%$ of the total variance in climbing, whereas anthropometric and flexibility components explained only $0.3 \%$ and $1.8 \%$. Most of the variability in climbing performance can, therefore, be explained by trainable variables and climbers do not necessarily need to have specific anthropometric characteristics to be successful at sport rock climbing. Several authors have also shown that high performance in climbing is mainly based on strength and endurance $3,4,9,10$.

It is evident that the determination of components related to climbing performance needs further investigation. In particular, there is a lack of scientific research focusing on the role of nutrition in sport climbing performance. Nutrition is a key determinant of sport performance. In addition to anecdotal references to eating disorders and unrealistic weight reduction practices in climbers, the limited published data in this area report a $20-40 \%$ energy deficit compared to target-based recommendations ${ }^{11-13}$.

Specific nutritional recommendations for climbers do not currently exist. Nutrition strategies should focus on providing adequate substrate stores to meet the fuel demands and nutrient requirements of the sport, while supporting an adequate body composition and reducing or delaying factors that would otherwise cause fatigue ${ }^{14}$.

The aim of this study was to study the dietary adequacy of a group of Spanish rock climbers on three different days: non-climbing, climbing-gym training and rock-climbing training days, as well as their body composition, in order to identify possible inadequacies in the diet that could be affecting their athletic performance.

\section{Material and method}

The study was designed as an observational, descriptive, crosssectional study.

\section{Participants}

An invitation to participate in the study was sent by email to the members of all the mountain-sport clubs and climbing-gyms listed on the web page of the Mountaineering Federation in the Community of Madrid (Spain). The email explained the aim of the study, the inclusion and exclusion criteria and gave a detailed explanation of what was expected from the participating volunteers. This invitation was also disseminated through social media channels. Climbers interested in participating were asked to contact the research team for a personal interview to clarify their participation in the project and to book a second visit to take measurements and complete the questionnaires.

Inclusion criteria were: Healthy men and women over 18 years old, to not be following a special diet, to have been practicing climbing for at least one year and to have practice outdoor rock-climbing regularly (at least once a week) during the study period. Exclusion criteria included: Individuals with a chronic illness or who experienced any type of injury immediately before and/or during the study period, and for women, being pregnant or breastfeeding.

A total of 105 volunteers replied to the invitation and the final sample population was composed of 61 individuals. Written informed consent was obtained from each participant according to the study design approved by the Committee for Ethical Research of the Universidad CEU-San Pablo, CEU Universities, Subcommittee on Clinical and Human Trials (code: 246/18/09). Participants received individual feedback to improve their food intake and body composition.

\section{Anthropometry}

Two ISAK (International Society for the Advance of the Kineanthropometry) Level III-certified anthropometrists performed the measurements included in the anthropometric restricted- profile ${ }^{15}$.

Body mass was measured using a portable scale (SECA 710, precision $0.1 \mathrm{~kg}$ ) while height was evaluated to the nearest $1 \mathrm{~mm}$ with a portable stadiometer (SECA 213). Body mass index (BMI) was then calculated from these measurements as weight $(\mathrm{kg}) /$ height $(\mathrm{m})^{2}$.

Skinfold measurements were taken using a Harpenden ${ }^{\circledR}$ skinfold caliper (measuring range: $0 \mathrm{~mm}$ to $80 \mathrm{~mm}$, measuring pressure: $10 \mathrm{~g} / \mathrm{mm}^{2}$, precision $0.2 \mathrm{~mm}$ ). Skinfolds were then used to estimate fat percent using the equation designed by Carter, according to the gender of the volunteer ${ }^{16}$. Arm span and girths were evaluated using an anthropometric metallic tape, precision $1 \mathrm{~mm}$ (CESCORF, Brazil). Bone breadths were measured with a small bone caliper (Holtain, UK) to the nearest $1 \mathrm{~mm}$.

All measurements were taken following the international standards for anthropometric assessment ${ }^{15}$, on the right side of the volunteers a minimum of two times. A third measurement was taken when both measurements differed by more than $5 \%$.

The anthropometric measurements were used to calculate the somatotype components of the subjects according to the Heath-Carter method $^{17}$.

\section{Dietary Intake}

Daily dietary intake was self-recorded on 3 days of the week: a) during one day without climbing $b$ ) during a day in which the volunteer trained at the climbing-gym and c) during a day in which the volunteer went rock climbing. Food amounts were recorded as common household measures. To ensure the accuracy of data, volunteers received specific oral guidelines and detailed written instructions on what to do, and were clearly requested not to alter their usual dietary behavior during 
this period. A telephone number was available for participants to clarify any doubts that could arise. Food records were carefully reviewed immediately after completion. During analysis of the questionnaires, when necessary subjects were contacted to clarify ambiguous information about portion sizes, types of foods, brand names, or cooking methods.

Reports were analyzed using nutrient analysis software (DIAL ${ }^{\oplus}$, Alce Ingeniería 2012).

To assess dietary adequacy, intakes were compared with the following recommendations:

- For energy intake, a personalized target was assigned to each participant, according to their energy needs for each of the three days studied. To determine individual energy needs, energy expenditure was calculated as follows: On the same day reported in the food diary, each volunteer filled in an activity diary in which he/she gave a detailed account of the time devoted to performing different work, leisure, daily life and sports activities during that day. The time dedicated to each activity was multiplied by the corresponding $M E T^{18}$ and the daily average MET/24h was then estimated. Finally, total energy expenditure was estimated by multiplying the average $\mathrm{MET} / 24 \mathrm{~h}$ by the basal metabolic rate of the subject, which had been calculated using $\mathrm{WHO}$ equations ${ }^{19}$.

- For protein intake, two targets were established. The first one $1.7 \mathrm{~g} \times \mathrm{kg}$ body weight, following recommendations for strength type sports included in the position paper of the Academy of Nutrition and Dietetics, Dietitians of Canada, and the American College of Sports Medicine ${ }^{14}$. The second target for protein intake was established as 15\% percent of total energy intake, according to the Acceptable Macronutrient Distribution Ranges (AMDR) specified in the Spanish Nutritional Objectives by the Spanish Society for Public Health Nutrition ${ }^{20}$.

- The same procedure was followed to establish targets for carbohydrate $(\mathrm{CHO})$ intake. The first target was $6 \mathrm{~g} / \mathrm{kg}$ body weight, a recommended target for endurance training programs $(1-3 \mathrm{~h} / \mathrm{d})^{14}$. The second target was 50-55\% of total energy intake, AMDR in the Spanish Nutritional Objectives for a healthy population. For sugars, an intake less than $10 \%$ of total energy intake was recommended ${ }^{20}$.

- Fat target recommendations were those from the Spanish Nutritional Objectives ${ }^{20}$. Total fat intake 30-35\%; Saturated fatty acids (SFA) 7-8\% of total energy intake; Monounsaturated fatty acids (MUFA) $20 \%$ of total energy intake; Polyunsaturated fatty acids (PUFA) $5 \%$ of total energy intake; Trans fatty acids less than $2 \mathrm{~g}$ /day.

- Recommendations for general population were followed to study the adequacy of fiber intake: $25 \mathrm{~g} /$ day was the target for women and $35 \mathrm{~g} /$ day for men ${ }^{20}$.

- Recommended Nutrient Intake for the Spanish population ${ }^{21}$ was used as targets for vitamin and mineral intakes.

Compliance with the above recommendations was calculated as (nutrient intake x 100)/recommended intake. Overall diet quality was measured by calculating Mean Adequacy Ratio (MAR) ${ }^{22}$. This index quantifies the overall nutritional adequacy of a population, based on an individual's diet using the recommended allowance for a group of nutrients of interest. For this population group, nutrients considered of interest by the researches were those related to energy intake and to muscular and skeletal health: energy, proteins, carbohydrates, thiamin, riboflavin, niacin, vitamin B6, folates, vitamin B12, calcium, iron and magnesium.

First, the NAR, Nutrient Adequacy Ratio was calculated for each of the mentioned nutrients, as the percentage of an individual's nutrient intake relative to the recommended allowance of the nutrient for his or her age and sex. NAR values over $100 \%$ were set to a maximum of $100 \%$. Then the MAR was obtained by estimating the mean of all the NAR values:

\section{$M A R=\sum N A R /$ number of nutrients}

The MAR was reported on a scale from 0 to $100 \%$, where $100 \%$ indicates the requirements for all the nutrients were met.

\section{General questionnaire}

A specific questionnaire was designed to record socioeconomic data (age, sex, profession, and interest in other sports) medical history (diseases, pharmacological treatments, injuries background) and climbing background and habits (years of practice, days of training/week (minimum one hour of training per day), main sporting achievements, onsight and redpoint grade).

According to their redpoint grade, climbers were classified following the IRCRA (International Rock Climbing Research Association) scale and then categorized into 5 groups: low grade, intermediate grade, advanced grade, elite and high elite grade ${ }^{23}$.

\section{Statistics}

Results for categories are reported using frequencies and percentages, while continuous variables are reported using mean \pm standard deviation.

Differences in nutrient adequacy between men and women were analysed by the student $T$ test; while differences among the three studied days were analysed by a Friedman test for repeated measures, followed by a $T$ test for paired variables when statistical differences were found.

Relationships between the quality of the diet and climbing performance were studied after grouping the volunteers according to the number of training days (2 days/week; 3 days/week; 4 day/s week). In each group, a Spearman's correlation was performed between MAR and IRCRA level and differences in MAR in the different IRCRA categories were analysed by a Kruskall Wallis test.

For all statistical analyses, differences were considered significant at $P<0.05$. Statistical analyses were performed using SPSS V.24.0 (IBM Corp., Armonk, NY, USA).

\section{Results}

A total of 61 climbers (44 men, 17 women), mean age of $34 \pm 8$ years, participated in the study. Participants' climbing background, training and grade reached are shown in Table 1. Volunteers had been climbing for an average of $8 \pm 6$ years without significant gender differences. Climbing ability, according to both onsight and redpoint grade, was significantly greater in males compared to females $(p<0.05)$. A total of $42 \%$ of men and $58 \%$ of women were classified as intermediate climbers; $42 \%$ of 
Table 1. General characteristics of climbers (age, climbing background, training and reached grade) by gender groups.

\begin{tabular}{lcc}
\hline & $\begin{array}{c}\text { Men } \\
(\mathbf{n}=\mathbf{4 4 )}\end{array}$ & $\begin{array}{c}\text { Women } \\
(\mathbf{n = 1 7 )}\end{array}$ \\
\hline Age (years) & $34.3 \pm 8.0$ & $34.9 \pm 8.5$ \\
Climbing background (years) & $9.2 \pm 6.5$ & $7.6 \pm 5.7$ \\
Training days/week & $3.6 \pm 1.1$ & $2.7 \pm 0.7^{*}$ \\
Bouldering (\% of participants) & 61.1 & 41.7 \\
Sport climbing (\% of participants) & 100 & 100 \\
Traditional Climbing (\% of participants) & 41.7 & 58.3 \\
Onsight grade (IRCRA Scale) & $16.6 \pm 3.7$ & $12.8 \pm 1.9^{*}$ \\
Redpoint grade (IRCRA Scale) & $19.1 \pm 3.9$ & $14.5 \pm 2.3^{*}$ \\
\hline
\end{tabular}

Data are expressed as mean \pm standard deviation

IRCRA: International Rock Climbing Research Association

${ }^{*} P<0.05$ between men and women.

Table 2. Anthropometric and body composition data of climbers by gender groups.

\begin{tabular}{lcc}
\hline & $\begin{array}{c}\text { Men } \\
(\mathbf{n}=\mathbf{4 4})\end{array}$ & $\begin{array}{c}\text { Women } \\
(\mathbf{n}=\mathbf{1 7})\end{array}$ \\
\hline Height $(\mathrm{cm})$ & $176.3 \pm 6.2$ & $163.1 \pm 4.1^{*}$ \\
Weight $(\mathrm{kg})$ & $69.4 \pm 6.9$ & $56.4 \pm 4.1^{*}$ \\
BMI $\left(\mathrm{kg} / \mathrm{m}^{2}\right)$ & $22.3 \pm 1.8$ & $21.2 \pm 1.8^{*}$ \\
Arm span $(\mathrm{cm}) /$ height $(\mathrm{cm})^{*} 100$ & $103.1 \pm 2.7$ & $101.8 \pm 2.9$ \\
\% body fat & $8.1 \pm 1.5$ & $15.7 \pm 3.0^{*}$ \\
Endomorphism & $2.1 \pm 0.6$ & $3.4 \pm 0.9^{*}$ \\
Mesomorphism & $4.7 \pm 1.0$ & $4.0 \pm 1.0^{*}$ \\
Ectomorphism & $2.9 \pm 1.0$ & $2.6 \pm 0.9$ \\
\hline
\end{tabular}

Data are expressed as mean \pm standard deviation

${ }^{*} P<0.05$ between men and women.

men and women in the advanced level and 17\% of men in the elite group. As expected, the greater the number of training days a week, the higher the level obtained $(P<0.05)$.

Anthropometric and body composition data are shown in Table 2. Average $\mathrm{BMI}$ of participants was in normal range ${ }^{24}$, while body fat percentage was at low-healthy level $\mathrm{s}^{25}$ in both men and women. Average arm span/height*100 ratio, was over one hundred units in both genders. Somatotype values indicate a mesomorphic body shape characterized by a moderate muscular and bone mass development. As expected, men had significantly less \% body fat, a lesser endomorphic index and a higher mesomorphic one. Consequently, the BMI was significantly higher in men than in women. No differences were seen in the ape index. We observed statistical differences $(P<0.05)$ in the percentage of body fat according to the different levels of the IRCRA classification. Elite climbing men had a lower body fat percentage compared to intermediate and advanced participants. Also, a statistically significant negative correlation was found between percentage of body fat and range in the IRCRA scale $(P<0.0005)$, this correlation being stronger in men than in women.
Global dietary intakes and intakes on each of the three analyzed days are shown in Table 3. Energy intake was low compared to the estimated energy expenditure in both genders: $41 \%$ energy deficiency was observed in men (they met 59\% of their energy requirement) and $38 \%$ in women (they met $62 \%$ of their energy requirement), on the average three evaluated days. This deficiency was more remarkable on the rock-climbing day (57\% of deficiency in men and 36\% in women) and on the climbing- gym day (43\% of deficiency in men and $37.5 \%$ in women) than on the non-climbing day (28\% of deficiency in men and $25 \%$ in women) with statistical differences among the three days $(P<0.001)$. Protein and $\mathrm{CHO}$ intakes were also lower than the targets (20$25 \%$ of deficiency in proteins and $43-49 \%$ for $\mathrm{CHO}$ ). These results were quite similar in men and women and also on the three days studied. The macronutrient distribution range of the energy is shown in Table 3. Lipid contribution to energy intake was high in both genders and on all the days, when compared to Spanish Nutritional Objectives ${ }^{20}$ and to athlete's recommendations ${ }^{14}$, while the carbohydrate contribution to energy was below recommendations. We observed an elevated intake of SFA and a low MUFA intake. Sugar consumption was high and fiber was low on all evaluated days and in both genders.

Micronutrient intakes (Table 4) were acceptable except for iodine, zinc and vitamin D in the case of men. Zinc, iron, folate, vitamin D and vitamin $E$ intakes showed deficiencies in women. Intakes of iron and folate were significantly lower in women $(P<0.05)$ than men on the non-climbing day.

There was a positive correlation between climbing ability and the quality of the diet (MAR) on the non-climbing day $(P=0.005)$. After grouping the climbers by similar loads of training (number of training days per week) (Table 5), we observed a higher MAR in advanced/elite level climbers compared to intermediate level volunteers, on the three different days and in the average of the 3 day study period, being statistically significant in the average 3 day study period $(P=0.046)$ and on the rock climbing day $(P=0.043)$ in the group that trained 3 days a week.

\section{Discussion}

The present study examined the diet of a group of Spanish climbers on three different days: non-climbing, climbing-gym training and rockclimbing day, as well as their body composition. This study is unique in that it takes into account the whole dietary intake of participants of this sport.

Men trained significantly more days a week than women and reached a higher grade (19vs 15 redpoint grade). Anthropometric characteristics (height, weight, BMI, \% body fat) of volunteers were similar to those reported in some previous studies $2,5,26,27$ and have slightly higher values from others studies performed in elite climbers ${ }^{4,6,28-31}$. In any case, our results show that climbers are not small in stature ${ }^{32}$, and have a low body mass and low body fat percentage. For some authors ${ }^{13,33}$, the central issue appears to be specific body proportions rather than body size, and characteristics such as arm span may be of greater importance when selecting subjects for competitive sport climbing. In our study, arm span was greater than body height in men and women and, consequently, the index arm span/height (or ape index) is over 1.0, as also shown by other authors $6,29,31,33$. 
Table 3. Macronutrient intake compared to estimated targets. Average of the 3 day study period, non-climbing day, climbing-gym day training and rock climbing day training.

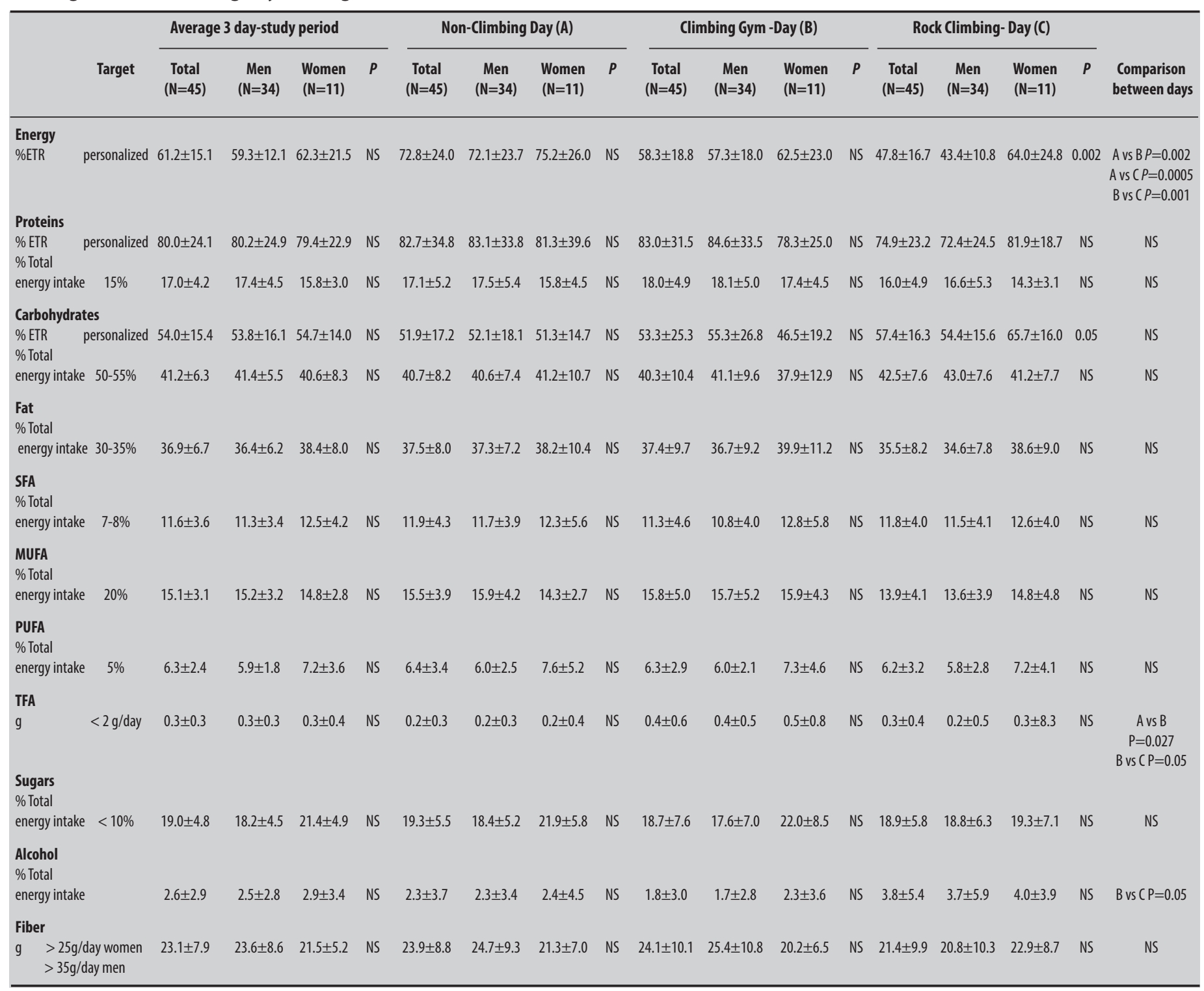

Data are expressed as mean \pm standard deviation.

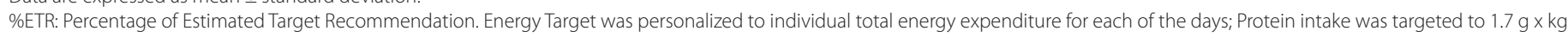
body/weight and Carbohydrate intake target was estimated as $6 \mathrm{~g} \times \mathrm{kg}$ body weight.

SFA: Saturated fatty acids; MUFA: Monounsaturated fatty acids; PUFA: Polyunsaturated fatty acids, TFA: Trans fatty acids.

Regarding body fat, in our study, climbers with better performance (elite level) had a lower percentage body fat than those in the advanced or intermediate level. A statistically significant negative correlation was found between percentage of body fat and range on the IRCRA scale, and this correlation was stronger in men than in women. In this regard, although these anthropometric characteristics are not necessarily required to attain the top level of climbing performance, they may be considered beneficial for success in climbing ${ }^{33}$.
The main nutritional findings in this study were that energy, protein and carbohydrate intake were low compared to estimated targets in both genders. In the case of energy and carbohydrates, an approximate deficiency of $40 \%$ was observed, and for proteins $20-25 \%$ deficiency was reported. Whereas protein and carbohydrate intake were similar on the three evaluated days, energy consumption was significantly different, being the lowest on the rock-training day. Climbers usually report a lack of appetite on the rock-climbing training day. It is well-documented that 
Table 4. Percent of Spanish Dietary Recommended Intakes (\%DRI) covered by the diet of volunteers. Average of the 3 days study period; non-climbing day, climbing-gym day training and rock-climbing day training

\begin{tabular}{|c|c|c|c|c|c|c|c|c|c|c|c|c|c|c|c|c|c|}
\hline & \multicolumn{4}{|c|}{ Average 3 day-study period } & \multicolumn{4}{|c|}{ Non-Climbing Day (A) } & \multicolumn{4}{|c|}{ Climbing Gym -Day (B) } & \multicolumn{4}{|c|}{ Rock Climbing-Day (C) } & \multirow[b]{2}{*}{$\begin{array}{l}\text { comparison } \\
\text { between days }\end{array}$} \\
\hline & $\begin{array}{c}\text { Total } \\
(\mathrm{N}=45)\end{array}$ & $\begin{array}{c}\text { Men } \\
(\mathrm{N}=34)\end{array}$ & $\begin{array}{l}\text { Women } \\
(\mathrm{N}=11)\end{array}$ & $P$ & $\begin{array}{c}\text { Total } \\
(\mathrm{N}=45)\end{array}$ & $\begin{array}{c}\text { Men } \\
(\mathrm{N}=34)\end{array}$ & $\begin{array}{l}\text { Women } \\
(\mathrm{N}=11)\end{array}$ & $P$ & $\begin{array}{l}\text { Total } \\
(\mathrm{N}=45)\end{array}$ & $\begin{array}{c}\text { Men } \\
(\mathrm{N}=34)\end{array}$ & $\begin{array}{l}\text { Women } \\
(\mathrm{N}=11)\end{array}$ & $P$ & $\begin{array}{c}\text { Total } \\
(\mathrm{N}=45)\end{array}$ & $\begin{array}{c}\text { Men } \\
(\mathrm{N}=34)\end{array}$ & $\begin{array}{l}\text { Women } \\
(\mathrm{N}=11)\end{array}$ & $P$ & \\
\hline \multicolumn{18}{|l|}{ Minerals } \\
\hline Calcium & $81.2 \pm 23.6$ & $80.4 \pm 21.7$ & $83.3 \pm 29.2$ & NS & $78.8 \pm 29.4$ & $77.6 \pm 28.6$ & $82.3 \pm 33.0$ & NS & $78.5 \pm 30.7$ & $77.3 \pm 28.0$ & $82.1 \pm 39.4$ & NS & $85.5 \pm 37.6$ & $87.4 \pm 38.8$ & $84.2 \pm 35.6$ & NS & NS \\
\hline Iron & $129.5 \pm 54.1$ & $149.9 \pm 46.9$ & $71.7 \pm 21.5$ & 0.0005 & $131.6 \pm 62.8$ & $154.3 \pm 53.8$ & $61.3 \pm 24.0$ & 0.0005 & $5133.3 \pm 66.4$ & $153.0 \pm 63.6$ & $72.5 \pm 26.30$ & 0.0005 & $512.3 \pm 62.9$ & $145.5 \pm 65.4$ & $83.6 \pm 17.3$ & 0.004 & NS \\
\hline lodine & $68.0 \pm 23.9$ & $65.8 \pm 25.8$ & $74.1 \pm 16.8$ & NS & $70.0 \pm 33.7$ & $68.8 \pm 35.9$ & $73.6 \pm 27.1$ & NS & $64.3 \pm 33.3$ & $62.9 \pm 33.2$ & $68.8 \pm 34.8$ & NS & $69.5 \pm 36.6$ & $65.3 \pm 38.9$ & $81.1 \pm 27.6$ & NS & NS \\
\hline Zinc & $63.3 \pm 20.5$ & $64.7 \pm 20.7$ & $59.3 \pm 20.4$ & NS & $61.3 \pm 22.1$ & $64.8 \pm 22.5$ & $50.4 \pm 17.4$ & NS & $69.4 \pm 31.4$ & $70.9 \pm 32.8$ & $65.0 \pm 27.4$ & NS & $59.9 \pm 26.2$ & $58.7 \pm 26.4$ & $63.3 \pm 26.6$ & NS & Bvs $C P=0,05$ \\
\hline Magnesium & $92.5 \pm 26.5$ & $93.1 \pm 28.7$ & $91.0 \pm 19.8$ & NS & $86.6 \pm 26.4$ & $88.1 \pm 28.4$ & $81.9 \pm 19.2$ & NS & $98.0 \pm 39.3$ & $100.6 \pm 43.1$ & $89.9 \pm 23.7$ & NS & $95.1 \pm 34.9$ & $92.2 \pm 35.7$ & $103.4 \pm 32.5$ & NS & NS \\
\hline Potassium & $82.1 \pm 21.3$ & $85.0 \pm 22.9$ & $73.7 \pm 13.5$ & NS & $83.7 \pm 26.1$ & $87.8 \pm 26.9$ & $71.0 \pm 19.2$ & NS & $87.5 \pm 28.1$ & $91.1 \pm 30.0$ & $76.3 \pm 185$ & NS & $74.6 \pm 25.6$ & $75.4 \pm 27.9$ & $72.6 \pm 19.9$ & NS & NS \\
\hline Phosphorum & $202.7 \pm 53.7$ & $206.6 \pm 51.8$ & $191.5 \pm 59.6$ & NS & $197.3 \pm 63.3$ & $203.4 \pm 61.2$ & $178.3 \pm 69.0$ & NS & $207.2 \pm 73.3$ & $213.9 \pm 72.2$ & $186.6 \pm 76.4$ & NS & $206.8 \pm 72.4$ & $205.1 \pm 75.8$ & $211.5 \pm 65.3$ & NS & NS \\
\hline Selenium & $162.2 \pm 49.6$ & $158.6 \pm 49.1$ & $180.3 \pm 49.4$ & NS & $162.7 \pm 80.3$ & $158.2 \pm 79.3$ & $176.5 \pm 85.5$ & NS & $176.3 \pm 78.6$ & $174.2 \pm 77.6$ & $182.9 \pm 85.4$ & NS & $153.6 \pm 59.0$ & $140,9 \pm 62.1$ & $189.6 \pm 28.0$ & 0.02 & NS \\
\hline \multicolumn{18}{|l|}{ Vitamins } \\
\hline Tiamin & $127.7 \pm 68.8$ & $137.1 \pm 73.7$ & $101.2 \pm 44.8$ & NS & $142.2 \pm 105.4$ & $157.4 \pm 104.6$ & $95.0 \pm 69.0$ & NS & $119.1 \pm 54.3$ & $122.9 \pm 52.2$ & $107.1 \pm 61.4$ & NS & $123.8 \pm 55.5$ & $131.5 \pm 59.8$ & $102.2 \pm 34.5$ & NS & NS \\
\hline Riboflavin & $109.1 \pm 54.0$ & $112.9 \pm 60.3$ & $98.2 \pm 29.5$ & NS & $120.7 \pm 125.2$ & $130.5 \pm 123.4$ & $90.3 \pm 37.3$ & NS & $102.8 \pm 45.2$ & $103.8 \pm 46.6$ & $99.5 \pm 42.8$ & NS & $103.1 \pm 49.8$ & $103.7 \pm 54.4$ & $101.5 \pm 35.9$ & NS & NS \\
\hline Niacin & $261.1 \pm 206.2$ & $245.4 \pm 228.8$ & $305.5 \pm 261.2$ & NS & $267.1 \pm 204.6$ & $251.9 \pm 231.8$ & $314.4 \pm 294.8$ & NS & $271.6 \pm 201.8$ & $253.1 \pm 220.2$ & $328.8 \pm 284.4$ & 4 NS & $164.1 \pm 66.0$ & $172.6 \pm 71.2$ & $140.2 \pm 42.6$ & NS & NS \\
\hline vit. B6 & $141.1 \pm 41.9$ & $148.7 \pm 44.6$ & $119.5 \pm 22.5$ & 0.04 & $132.1 \pm 82.5$ & $142.1 \pm 91.1$ & $101.2 \pm 33.9$ & NS & $131.6 \pm 48.0$ & $132.2 \pm 52.0$ & $117.5 \pm 30.6$ & NS & $129.0 \pm 49.7$ & $129.7 \pm 53.5$ & $127.3 \pm 39.2$ & NS & NS \\
\hline Folate & $74.8 \pm 26.2$ & $78.7 \pm 27.5$ & $63.7 \pm 19.6$ & NS & $77,6 \pm 38.8$ & $85.0 \pm 40.3$ & $54.5 \pm 22.7$ & 0.02 & $76.3 \pm 37.3$ & $78.4 \pm 39.1$ & $70.1 \pm 32$ & NS & $71.2 \pm 35.4$ & $72.9 \pm 39.5$ & $66.4 \pm 20.4$ & NS & NS \\
\hline vit. B12 & $279.6 \pm 126.9$ & $290.4 \pm 130.4$ & $248.9 \pm 116.4$ & NS & $293.8 \pm 253.6$ & $295.2 \pm 257.6$ & $289.5 \pm 252.1$ & NS & $299.2 \pm 190.1$ & $304.1 \pm 200.9$ & $283.8 \pm 159.4$ & 4 NS 2 & $251.9 \pm 149.4$ & $66.4 \pm 20.4$ & $201.8 \pm 85.3$ & NS & NS \\
\hline vit. C & $247.4 \pm 129.4$ & $248.4 \pm 135.1$ & $241.0 \pm 117.2$ & NS & $267.3 \pm 178.4$ & $271.2 \pm 193.6$ & $255.2 \pm 127.1$ & NS & $269.3 \pm 156.9$ & $264.3 \pm 156.1$ & $284.5 \pm 166.1$ & 1 NS 1 & $194.3 \pm 142.8$ & $200.8 \pm 160.3$ & $175.8 \pm 77.7$ & NS & $\begin{array}{l}\text { Avs } B=0.001 \\
\text { Bvs } C P=0.0005\end{array}$ \\
\hline vit. A & $160.9 \pm 78.4$ & $158.3 \pm 77.4$ & $168.4 \pm 84.2$ & NS & $118.7 \pm 74.7$ & $122.0 \pm 80.7$ & $108.3 \pm 53.9$ & NS & $97.5 \pm 74.6$ & $91.8 \pm 65.1$ & $115.1 \pm 100.1$ & NS & $85.2 \pm 64.7$ & $76.9 \pm 53.5$ & $108.3 \pm 88.3$ & NS & AvsB $P=0.007$ \\
\hline vit. D & $20.4 \pm 15.5$ & $23.4 \pm 16.5$ & $11.8 \pm 7.0$ & NS & $19.9 \pm 16.9$ & $21.8 \pm 17.1$ & $14.1 \pm 15.8$ & NS & $22.5 \pm 24.0$ & $25.5 \pm 26.3$ & $13.5 \pm 11.5$ & NS & $18.5 \pm 24.3$ & $21.9 \pm 27.7$ & $8.9 \pm 3.4$ & NS & NS \\
\hline vit. E & $81.5 \pm 35.0$ & $84.8 \pm 37.1$ & $72.2 \pm 27.2$ & NS & $82.1 \pm 61.0$ & $83.9 \pm 63.3$ & $76.8 \pm 47.3$ & NS & $91.5 \pm 53.2$ & $991.1 \pm 56.3$ & $67.9 \pm 34.4$ & NS & $71.9 \pm 44.8$ & $70.1 \pm 47.2$ & $77.0 \pm 38.8$ & NS & NS \\
\hline vit. K & $112.3 \pm 160.7$ & $104.0 \pm 56.5$ & $136.0 \pm 67.9$ & NS & $114.0 \pm 85.4$ & $113.1 \pm 92.5$ & $117.0 \pm 61.6$ & NS & $131.8 \pm 113.2$ & $116.8 \pm 82.5$ & $178.0 \pm 175.5$ & NS & $87.5 \pm 79.7$ & $79.2 \pm 79.8$ & $110.4 \pm 78.5$ & NS & NS \\
\hline
\end{tabular}

Data are expressed as mean \pm standard deviation.

Table 5. Differences in Mean Adequacy Ratio (MAR) between intermediate and advance/elite climbers by groups of training load. Average of the 3 days, non-climbing day; climbing-gym day and rock-climbing day.

\begin{tabular}{|c|c|c|c|c|c|c|c|c|}
\hline & $\begin{array}{l}\text { Average } 3 \text { day- } \\
\text { study period }\end{array}$ & $P$ & $\begin{array}{l}\text { Non-Climbing } \\
\text { Day (A) }\end{array}$ & $P$ & $\begin{array}{c}\text { Climbing } \\
\text { Gym -Day (B) }\end{array}$ & $P$ & $\begin{array}{c}\text { Rock C } \\
\text { limbing- Day (C) }\end{array}$ & $P$ \\
\hline \multicolumn{9}{|l|}{$3 \mathrm{~d} / \mathrm{w}$ training } \\
\hline Intermediate & $76.6 \pm 2.6$ & & $71.2 \pm 10.6$ & & $77.6 \pm 6.4$ & & $68.2 \pm 12.05$ & \\
\hline Advanced/Elite & $79.6 \pm 9.6$ & 0.046 & $78.2 \pm 11.4$ & 0.128 & $78.2 \pm 11.5$ & 0.647 & 82.710 .6 & 0.043 \\
\hline \multicolumn{9}{|l|}{$4 \mathrm{~d} / \mathrm{w}$ training } \\
\hline Intermediate & $78.6 \pm 7.9$ & & $74.9 \pm 7.3$ & & $73.8 \pm 10.8$ & & $78.5 \pm 13.9$ & \\
\hline Advanced/Elite & $79.6 \pm 3.3$ & 0.481 & $79.6 \pm 10.6$ & 0.659 & $79.11 \pm 9.4$ & 0.649 & $72.8 \pm 2.2$ & 0.600 \\
\hline
\end{tabular}

Data are expressed as mean \pm standard deviatio.

exercise decreases orexigenic peptide (acylated ghrelin) and increases anorexigenic peptides (i.e., PYY and GLP-1) during and immediately after an acute bout of exercise ${ }^{34}$. Exercise can also influence other hormones related to appetite, such as cortisol and insulin ${ }^{35}$. These hormonal changes often coincide with a transient reduction in subjective appetite responses, described as "exercise-induced anorexia". Additionally, climbing is a stressful situation. Stress activates anorexigenic pathways leading to a decreased food intake. The general assumption can be made that acute or repeated restraint stress results in decreased food intake resulting in stress-induced anorexia ${ }^{36}$. Furthermore, compensation intake does not occur when energy deficits are generated by exercise ${ }^{37}$. Both factors (exercise and stress) could lead to LEA (low energy availability) a situation with negative health and performance outcomes ${ }^{38}$ that should be further study in climbers.

Similar results to ours were found by Zapf et al. and Merrells et al. ${ }^{11,12}$ in adult elite climbers and Michael et al. ${ }^{13}$ in adolescent rock climbers. Therefore, all results together show the urgent need for nutritional advice in this group of athletes. 
The mean macronutrient contribution to energy was unbalanced (protein: fat: $\mathrm{CHO}$ : alcohol to energy intake was 17:38:42:3\% respectively) and this macronutrient distribution, as well as other dietary characteristics (elevated intake of SFA and sugars and low MUFA and fiber intakes), are similar to those found in studies of the general Spanish population ${ }^{39}$.

To the best of our knowledge, this is the first study to assess micronutrient intake in climbers. Intakes of vitamins and minerals were acceptable except for iodine, zinc and vitamin D in the case of men. On the other hand, zinc, iron, folate, vitamin D and vitamin E were deficient in women. Intakes of iron and folate were significantly lower in women than men on the non-climbing day. Both nutrients are critical for the correct transport of oxygen by blood and the prevention of anemia. Folate also plays an essential role in amino acid metabolism and DNA synthesis. These inadequacies were similar to those shown by Partearroyo et al..$^{40}$ in the ANIBES study in Spain in the general population, indicating that the volunteers of the present study had typical Spanish eating habits rather than an athlete's diet in which nutrition strategies focus on providing adequate substrate stores to meet the fuel demands and nutrient requirements of the sport ${ }^{14}$. It is important to bear in mind that dietitians do not usually work in climbing-gyms in Spain; so, apart from personal interest, it is not easy to find nutritional advice or recommendations when practicing this type of sport even when aiming to professionalize.

Despite the lack of available advice, in general the quality of the diet calculated as the Mean Adequacy Ratio (MAR), which focuses on the nutrients involved in energy metabolism and bone-muscular health, was adequate for men and women on the three days evaluated. After grouping the volunteers by similar training load, i.e. those training for 3 or more days a week, we observed a higher MAR in advanced/elite level climbers compared with intermediate level ones, being statistically significant on the rock-climbing day. Furthermore, there was a positive correlation between climbing ability and MAR on the non-climbing day. These results indicate a potential relationship between climbing ability and the quality of the diet that could, therefore, be responsible for a significant part of the factors involved in performance. Consequently, we consider that acquiring good food habits could significantly improve climbing performance, although this should be studied in larger samples in the future.

\section{Conclusion}

This study in recreational climbers reveals that they have anthropometric characteristics similar to other studies performed in this sport, which differ according to climbing ability (with less body fat related to better performance). However, the dietary intakes failed to meet recommendations for energy, macronutrients and some micronutrients, which could negatively affect their physical performance. We described a possible relationship between climbing ability and the quality of the diet that should be evaluated further. Results indicate a need for specific nutritional recommendations for climbers. The present research could help to better understand the real needs of participants of this sport and support a need for evidence-based food intake recommendations specifically targeting this population.

\section{Strengths and limitations}

The main strength of the present study is the novelty of the dietary data, recorded on three different days: non-climbing day, climbing-gym day and rock-climbing day, including, in this way, all possible training situations and assessing the difference between them, in addition to a "rest day". Furthermore, anthropometric measurements were assessed by two ISAK level III-certified anthropometrists, ensuring the accuracy of the measurements.

However, some limitations should also be noted. First, the selfreported dietary records introduce the possibility of under or over reported food intake. The need to estimate portion sizes is also a wellknown limitation of the register method in household measures. We tried to limit this by giving oral and written instructions and by doublechecking the final reports.

Finally, it is impossible to know the exact number of people practicing climbing in Madrid, as the the Mountaineering Federation in the Community of Madrid (Spain) does not distinguish between members who practice climbing and those who practice any other mountain sport. This, together with the fact that only one of every four people who practice climbing is officially federated makes it impossible to determine the real statistical power of the sample size. In spite of this, comparing our findings with other research studies of the same population and taking into account the unique nature of the target population, we believe that the present results can be considered as representative.

\section{Acknowledgements}

We would like to thank The Mountaineering Federation of Madrid and the close collaboration of the users and management team of The Climb, Indoorwall Griñón, Rock 30 and the Climbing-Gym of the University of Alcalá de Henares, and their willingness to help us during the field-work of this research.

\section{Authors' contributions}

The study was designed by Nú; data were collected and analyzed by NÚ, CL-C and ÁG-G; data were interpreted by ÁG and Nú; manuscript preparation was undertaken by NÚ and ÁG. All authors approved the final version of the paper.

\section{Conflicts of Interest}

The authors do not declare a conflict of interest.

\section{Bibliography}

1. Ozimek M, Staszkiewicz R, Rokowski R, Stanula A. Analysis of Tests Evaluating Sport Climbers'Strength and Isometric Endurance. J Hum Kinet. 2016;53:249-260.

2. Booth J, Marino F, Hill C, Gwinn T. Energy cost of sport rock climbing in elite performers. Br J Sports Med. 1999;33:14-8.

3. España-Romero V, Ortega Porcel FB, Artero EG, Jiménez-Pavón D, Gutiérrez Sainz A, Castillo Garzón MJ, et al. Climbing time to exhaustion is a determinant of climbing performance in high-level sport climbers. Eur J Appl Physiol. 2009;107:517-25.

4. Grant S, Hasler T, Davies C, Aitchison TC, Wilson J, Whittaker A. A comparison of the anthropometric, strength, endurance and flexibility characteristics of female elite and recreational and non-climbers. J Sports Sci. 2001;19(7):499-505. 
5. Mermier CM, Janot JM, Parker DL, Swan J.G. Physiological and anthropometric determinants of sport climbing performance. Br J Sports Med. 2000;34:359-65; discussion 66.

6. Watts PB, Joubert LM, Lish AK, Mast JD, Wilkins B. Anthropometry of young competitive sport rock climbers. Br J Sports Med. 2003;37:420-4.

7. España-Romero V, Artero EG, Ortega FB, Jiménez-Pavón D, Gutiérrez A, Castilllo MJ, et al. Physiology of Sport Climbing (Aspectos fisiológicos de la escalada deportiva). Revista Internacional de Medicina y Ciencias de la Actividad Física y el Deporte. 2009;9(35):264-98.

8. Reilly T, Secher N, Snell P, Williams C. Anthropometry. In: Secher N, Snell P, Williams C, (Eds.) Physiology of Sports. London: E. and F.N. Spon, 1990. p. 470-83.

9. MacLeod D, Sutherland DL, Buntin L, Whitaker A, Aitchison T, Watt l, et al. Physiologica determinants of climbing-specific finger endurance and sport rock climbing performance. J Sports Sci. 2007;25:1433-43.

10. Schweizer, A., Furrer, M. Correlation of forearm strength and sport climbing performance. Isokinet Exerc Sci. 2007;15:211-6.

11. Merrells KJ, Friel JK, Knaus M, Suh M. Following 2 diet-restricted male outdoor rock climbers: impact on oxidative stress and improvements in markers of cardiovascular risk. Appl Physiol Nutr Metab. 2008;33:1250-6.

12. Zapf J, Fichtl B, Wielgoss S, Schmidt W. Macronutrient intake and eating habits of elite rock climbers. Med Sci Sports Exerc. 2001;33:S72.

13. Michael MK, Joubert L, Witard OC. Assessment of Dietary Intake and Eating Attitudes in Recreational and Competitive Adolescent Rock Climbers: A Pilot Study. Front Nutr. 2019;6:64.

14. Thomas DT, Erdman KA, Burke LM. American College of Sport Medicine. Academy of Nutrition and Dietetics, Dietitians of Canada. Joint Position Statement. Nutrition and Athletic Performance. Med Sci Sport Exerc. 2016;48(3):543-68.

15. Stewart A, Marfell-Jones M, Olds T, de Ridder, H. International Standards for Anthropometric Assessment. Handbook. International Society for the Advance of Kineanthropometry. 2011.

16. Carter J. Body composition of Montreal Olympic athletes. In: Carter J (ed). Physical structure of Olympic athletes Part I: The Montreal Olympic Games Anthropological Project. Basel, Switzerland: Karger. 1982. p. 107-16.

17. Carter J. 2002. The Heath-Carter Anthropometric Somatotype-Instruction Manual; Available at: htth/cmvwsomatotypeorg/Heath_CarterManual.pdf. [accessed 02.09.2019].

18. Ainsworth BE, Haskell WL, Herrmann SD, Meckes N, Bassett DR, Tudor-Locke C, et al. Compendium of Physical Activities: A Second Update of Codes and METValues. Med. Sci. Sports Exerc. 2011:4:1575-81.

19. FAO/WHO/UNU. Energy and protein requirements. Report of a joint FAO/WHO/UNU Expert Consultation. Technical Report Series. № 724. WHO. Ginebra. 1985

20. Sociedad Española de Nutrición Comunitaria (SENC). Nutritional objectives for the Spanish population. Consensus of the Spanish Society of Community Nutrition. (Objetivos nutricionales para la población española. Consenso de la sociedad Española de Nutrición Comunitaria). Rev Esp Nutr Comunitaria. 2011;17(4):178-99.

21. Moreiras O, Carbajal A, Cabrera ML, Cuadrado C. Food composition tables (Tablas de Composición de Alimentos). 19a ed. Madrid. Pirámide. 2018.

22. INDDEX Project 2018, Data4Diets: Building Blocks for Diet-related Food Security Analysis. Tufts University, Boston, MA. Available at: https://inddex.nutrition.tufts.edu/ data4diets. [accessed 17.07.2019].

23. Draper N, Giles D, Schöffl V, Fuss F, Watts P, Wolf P, et al. Comparative grading scales, statistical analyses, climber descriptors and ability grouping: International Rock Climbing Research Association position statement'. Sports Technology. 2016;8(34):88-94.
24. World Health Organization. 2014. BMI Classification. Available at: http://apps.who.int/ bmi/index.jsp?introPage=intro_3.html. [accessed 02.09.2019].

25. Gallagher D, Heymsfield SB, Heo M, Jebb SA, Murgatroyd PR, Sakamoto Y. Healthy percentage body fat ranges: an approach for developing guidelines based on body mass index. Am J Clin Nutr. 2000;72(3):694-701.

26. Watts PB, Martin DT, Durtschi S. Anthropometric profiles of elite male and female competitive sport rock climbers. J Sports Sci.. 1993;11:113-7.

27. Watts PB, Daggett M, Gallagher P, Wilkins B. Metabolic response during sport rock climbing and the effects of active versus passive recovery. Int J Sports Med. 2000;21:185-90.

28. Grant S, Hynes V, Whittaker A, Aitchison T. Anthropometric, strength, endurance and flexibility characteristics of elite and recreational climbers. J Sports Sci. 1996;14:301-9.

29. Alvero-Cruz JR, Giner Arnabat L, Alacid Cárceles F, Rosety-Rodríguez MA, Ordóñez Muño, F.J. Somatotype, Fat and Muscle Mass of Elite Spanish Climbers (Somatotipo, Masa Grasa y Muscular del Escalador Deportivo Español de Elite). Int. J. Morphol. 2011;29(4):1223-130.

30. España-Romero V, Ortega-Porcel F, García-Artero E, Ruiz JR, Gutiérrez-Sainz A. Performance, anthropometric and muscle strength characteristics in Spanish elite rock climbers. Selección: Revista Española e Iberoamericana de la Medicina de la Educación Física y el Deporte. 2006;15:176-83.

31. España-Romero V, Ruiz JR, Ortega FB, Artero EG, Vicente-Rodríguez G, Moreno LA, et al. Body fat measurement in elite sport climbers: Comparison of skinfold thickness equations with dual energy X-ray absorptiometry. J Sport Sci. 2009;27(5):469-77.

32. OECD. 2009. "Height", in Society at a Glance 2009: OECD Social Indicators, OECD Publishing, Paris. DOI: https://doi.org/10.1787/soc_glance-2008-26-en [accessed 02.09.2019].

33. Tomaszewski P, Gajewski J, Lewandowska J. Somatic Profile of Competitive Sport Climbers. J Hum Kinet. 2011;29:107-13.

34. Schubert MM, Sabapathy S, Leveritt M, Desbrow B. Acute exercise and hormones related to appetite regulation: a meta-analysis. Sports Med. 2014;44(3):387-403.

35. Begg DP, Woods SC. The endocrinology of food intake. Nat Rev Endocrinol. 2013;9: 584-97.

36. Ans AH, Anjum I, Satija V, Inayat A, Asghar Z, Akram I, et al. Neurohormonal Regulation of Appetite and its Relationship with Stress: A Mini Literature Review. Cureus. 2018;10(7):e3032

37. King JA, Wasse LK, Ewens J, Crystallis K, Emmanuel J, Batterham RL, et al. Differential acylated ghrelin, peptide YY3-36, appetite, and food intake responses to equivalent energy deficits created by exercise and food restriction. J Clin Endocrinol Metab. 2011;96:1114-21.

38. Melin AK, Heikura IA, Tenforde A, Mountjoy M. Energy Availability in Athletics: Health, Performance, and Physique. Int J Sport Nutr Exerc Metab. 2019;29(2):152-64.

39. Ruiz E, Ávila JM, Valero T, del Pozo S, Rodriguez P, Aranceta-Bartrina J, Gil Á, et al. Energy Intake, Profile, and Dietary Sources in the Spanish Population: Findings of the ANIBES Study. Nutrients. 2016;7(6):4739-62.

40. Partearroyo T, Samaniego-Vaesken ML, Ruiz E, Varela-Moreiras G. Assessment of micronutrients intakes in the Spanish population: a review of the findings from the ANIBES study. Nutr Hosp. 2018;35 (No Extra. 6):20-4. 